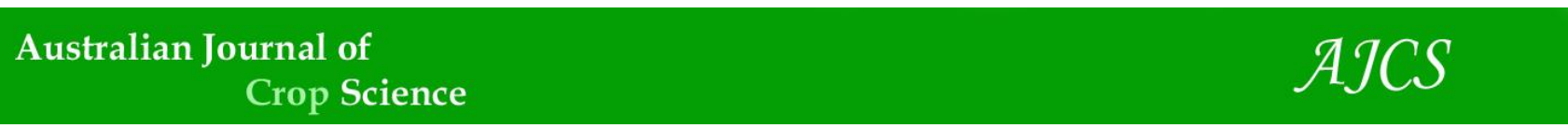

AJCS 10(3):307-313 (2016)

ISSN:1835-2707

DOI: 10.21475/ajcs.2016.10.03.p6864

\title{
Effects of silicon (Si) fertilization on gas exchange and production in Brachiaria
}

\author{
Marcos Vinícius Mansano Sarto ${ }^{1 *}$, Maria do Carmo Lana ${ }^{2}$, Leandro Rampim³ ${ }^{3}$ Jean Sérgio Rosset ${ }^{4}$, \\ Adriano Mitio Inagaki ${ }^{2}$, Doglas Bassegio ${ }^{1}$
}

${ }^{1}$ São Paulo State University (UNESP), Department of Crop Science, Lageado Experimental Farm, José Barbosa de Barros Street, 1780, P.O. Box 237, 18610-307 Botucatu, São Paulo, Brazil

${ }^{2}$ West Paraná State University (UNIOESTE), Center for Agriculture Sciences, Marechal Cândido Rondon,

Paraná, Brazil

${ }^{3}$ State University of Midwest (UNICENTRO), Guarapuava, Paraná, Brazil

${ }^{4}$ State University of Mato Grosso do Sul (UEMS), Mundo Novo, Mato Grosso do Sul, Brazil

"Corresponding author: marcos_sarto@hotmail.com, marcos.sarto28@gmail.com

\begin{abstract}
Calcium silicate $\left(\mathrm{CaSiO}_{3}\right)$ applied to the soil may increase $\mathrm{Si}$ content in the soil and plants, as well as reduce sweating and increase water use efficiency. In this study, we aimed to investigate whether the application of $\mathrm{CaSiO}_{3}$ increased $\mathrm{Si}$ content in plants and interfered with gas exchange and production components in Brachiaria. The experiment was performed using 8-L plastic pots in a greenhouse. Treatments were arranged in a randomized block design in a $3 \times 5$ factorial: three soils (Rhodic Acrudox, Rhodic Hapludox, and Arenic Hapludult) and five silicate rates $\left(0,1,2,4\right.$, and $6 \mathrm{t} \mathrm{ha}^{-1}$ of $\left.\mathrm{CaSiO}_{3} / \mathrm{MgSiO}_{3}\right)$ were used; four replications were performed. $\mathrm{CaSiO}_{3}$ application to the soil increases $\mathrm{Si}$ concentration in the leaves. Si in plants reduces internal $\mathrm{CO}_{2}$ concentration and increases the efficiency of water use and instantaneous carboxylation efficiency. In soils with low pH and a high $\mathrm{Al}^{+3}$ level, which is toxic, reduction in plant sweating increases the intrinsic efficiency of water use in Brachiaria. Si helped to alleviate the toxic effects of $\mathrm{Al}^{+3}$.
\end{abstract}

Keywords: calcium silicate; intercellular $\mathrm{CO}_{2}$ concentration; transpiration; efficient use of water.

Abbreviations: $A_{-}$carbon assimilation rate, $C_{i}$ internal concentration $\mathrm{CO}_{2}, E \_$transpiration, $g s_{-}$stomatal conductance, $W U E_{-}$water use efficiency.

\section{Introduction}

Brazil has about 100 million hectares of cultivated pastures, and many of them have already undergone 10 years of grazing; approximately $60 \%$ of the areas are in a state of advanced degradation (Barducci et al., 2009). On a short- and mid-term basis, more than 30 million hectares are going to be recovered, to be degraded or sharp production decline process (Sano et al., 2008). A reason for the resistance of Brachiaria grass in Cerrado soil may be its ability to absorb and accumulate $\mathrm{Si}$ in the epidermis of leaves, thereby reducing the toxic effects of aluminum (Al), manganese $(\mathrm{Mn})$, and iron $(\mathrm{Fe})$ and increasing phosphorus (P) availability (Cocker et al., 1998; Korndörfer et al., 2001). Tropical soils are highly weathered, acidic, and low in Si availability for plants. Limestone has been predominantly used to correct soil acidity; however, alternate corrective materials such as silicates are available, which increase soil $\mathrm{pH}$, provide $\mathrm{Ca}$ and $\mathrm{Mg}$, and neutralize toxic $\mathrm{Al}$ and available $\mathrm{Si}$ (Korndörfer et al., 2001; Sarto et al., 2014a; Sarto et al., 2015). $\mathrm{Si}$ has been considered an essential nutrient for mainly grasses, and $\mathrm{Zn}$ concentration is higher in monocots than in dicots (van Raij, 1991). This results in several benefits for plants, especially greater tolerance to insect attack (Epstein, 2001) and diseases (Marschner, 1995), reduced sweating (Datnoff et al., 2001; Marschner, 1995), and a higher photosynthetic rate due to improvement in leaf architecture (Deren, 2001). However, Si is still relatively unknown and rarely applied in agriculture.
In many cases, increase in $\mathrm{Si}$ availability has increased crop development and yield, and this nutrient can indirectly influence some photosynthetic and biochemical aspects, especially in plants under biotic or abiotic stress conditions (Ma and Yamaji, 2006). Maximum growth and biomass accumulation in plants that received $\mathrm{Si}$ application are associated with changes in plant architectures, making them more erect, improving the angle of the leaves and light interception, avoiding excessive self-shading, delaying senescence, increasing the structural rigidity of tissues, and improving photosynthesis and reducing lodging (Gong and Chen, 2012; Ma and Yamaji, 2008). These beneficial effects are attributable to Si deposited in the cell wall of various plant organs (Ma and Yamaji, 2006) and other mechanisms. High deposition of $\mathrm{Si}$ in tissues results in a physical barrier that enhances the strength and rigidity of the tissues. There are few studies on the effect of Si on plant nutrition, and most of the studies have reported aspects of wheat growth and the beneficial role of $\mathrm{Si}$ in resistance to biotic and abiotic stresses (Rizwan et al., 2012). In addition to this aspect, the beneficial effects of Si are not always observed (Dann and Muir, 2002). There is evidence that Si has no effect on dry matter yield in Brachiaria grasses under conditions of water stress (Melo et al., 2003). Increased photosynthetic capacity in plants may be related to the presence of $\mathrm{Si}$ in the system, which causes better arrangement of leaves, makes them upright and resistant to 
possible damage, and reduces evapotranspiration (Agarie et al., 1998). Studies on Si absorption and gas exchange are largely restricted to crops such as rice, wheat, sugarcane, and cucumber, but few studies have investigated the importance of $\mathrm{Si}$ in natural vegetation and pastures.

Considering that the use of silicate tends to be the most common agricultural practice in Brazil, improved understanding of the effect of $\mathrm{Si}$ on crops is essential for adopting management strategies for improving crop production. In this context, the purpose of this study was to investigate whether the application of calcium silicate $\left(\mathrm{CaSiO}_{3}\right)$ in the soil may increase Si content in Brachiaria and interfere with gas exchange and production components.

\section{Results and Discussion}

\section{Si absorption}

$\mathrm{Si}$ content in the leaves increased with the application of $\mathrm{CaSiO}_{3}$ to the soil (Fig 1). Si absorption capacity is the primary determinant of whether $\mathrm{Si}$ cell uptake may be improved by transpiration. This is consistent with the results of Korndörfer et al. (2010), who observed higher absorption of $\mathrm{Si}$ in both Brachiaria brizanta 'Marandu' and Brachiaria brizanta 'Mombasa' because of silicate application. Pereira et al. (2004) highlighted the existence of close links between foliar concentrations and the Si dose applied. This increase may be related to the higher nutrient content in the soil (Fonseca et al., 2009; Sarto et al., 2014b; Sarto et al., 2015), and grasses such as Brachiaria and Panicum are classified as accumulators because of their high capacity for accumulating $\mathrm{Si}$ (Ma et al., 2001).

\section{Gas exchange}

Carbon assimilation rate $(A)$ and stomatal conductance ( $g s$ )

$A$ and $g s$ of Brachiaria were not influenced statistically ( $\mathrm{p} \leq$ 0.05) because of $\mathrm{CaSiO}_{3}$ application to the soil (Figure 1). Average values of net carbon assimilation were 27.99, 28.61, and $29.93 \mu \mathrm{mol} \mathrm{CO} \mathrm{Cm}^{-2} \mathrm{~s}^{-1}$ and those of stomatal conductance were $0.2081,0.2101$, and $0.2533 \mathrm{mmol} \mathrm{H}_{2} \mathrm{O} \mathrm{m}^{-2} \mathrm{~s}^{-1}$ in Rhodic Acrudox (Ox1), Arenic Hapludult (Ult), and Rhodic Hapludox (Ox2) soils, respectively. This was consistent with the results obtained by Braga et al. (2009). Dias-Filho (2002) observed maximum gross leaf photosynthetic rates of $30 \mu \mathrm{mol} \mathrm{CO} \mathrm{Cm}^{-2} \mathrm{~s}$ ${ }^{1}$ for the grass 'Marandu' in a greenhouse.

\section{Internal $\mathrm{CO}_{2}$ concentration $\left(\mathrm{C}_{i} \mathrm{CO}_{2}\right)$}

A quadratic response to internal $C_{i}$ within a substomatic chamber was observed, with the minimum value at $2.64,2.86$, and $2.65 \mathrm{t} \mathrm{ha}^{-1}$ and 78.37, 63.13, and $95.50 \mathrm{ppm}$ in $\mathrm{Ox} 1$, Ult, and $\mathrm{Ox} 2$ soils, respectively. The results are consistent with those obtained by Ferraz et al. (2014), who found a reduction in $\mathrm{C}_{i} \mathrm{CO}_{2}$ in two cotton cultivars as a function of $\mathrm{Si}$ foliar application. In situations where $C_{i}$ is lower, the photosynthetic rate tends to be higher, and there is an inverse relationship between $C_{i}$ and photosynthetic rate (Concenço et al., 2008). However, this was not observed, and despite the reduction in $C_{i}$, there was no increase in the photosynthetic rate.

\section{Transpiration (E) and intrinsic water use efficiency (A/gs)}

In Ox2 soil, Si fertilization reduced the rate of $\mathrm{E}$ and increased $\mathrm{A} / \mathrm{gs}$, (a maximum value of $146.32 \mathrm{~A} / \mathrm{g}_{\mathrm{s}}$ at $2.9 \mathrm{t} \mathrm{ha}^{-1}$ ); however, similar findings were not obtained for Ox1 and Ult soils.
Higher sweating was observed in Ox2, probably due to the low $\mathrm{pH}$ and high soil content of toxic $\mathrm{Al}^{+3}, \mathrm{Al}^{+3}$ decreases the total concentration of chlorophyll, but the decline in rate and is even more severe (Vitorello et al., 2005; Wang et al., 2006). Silicate increases soil $\mathrm{pH}$ and reduces toxic $\mathrm{Al}^{+3}$ levels in plants (Sarto et al., 2014a; Sarto et al., 2015), thus reducing transpiration $(E)$ in Brachiaria; furthermore, the silica deposits in leaf tissues promote a reduction in the rate of $E$ (Dayanandam et al., 1983). According to Dias et al. (2014), reduction in $E$ demonstrated by Si-treated plants may be an important enhancement promoted by higher $\mathrm{Si}$ concentrations because it may lead to more plants tolerant to ex vitro environment. In addition, changes in the internal structure of leaves are determining factors for the acclimatization ability of a species (Hanba et al., 2002). These modifications promote reduced water loss and maintain plant water status; this may be related to the higher epicuticular wax deposition observed in Si-treated plants. Overall, plants under stress reduce stomatal conductance and transpiration and increase the efficiency of water use. Under these conditions, the rate of photosynthesis is also decreased (Ferraz et al., 2012), which was not observed in this experiment because net $A$ and $g s$ were not affected regardless of less $E$ in $\mathrm{Ox} 2$. According to Inoue and Ribeiro (1988), this phenomenon is mainly influenced by temperature and water vapor saturation. Under the same conditions, differences in sweating may indicate a high or less efficient stomatal mechanism, resulting in saving of water by the plant.

\section{Efficiency of water use (WUE) and instantaneous carboxylation efficiency $(\mathrm{A} / \mathrm{Ci})$}

Physiological $W U E$ and $A / C_{i}$ increased by $\mathrm{CaSiO}_{3}$ application to the soils. WUE showed a peak at $2.63,2.51$, and $2.40 \mathrm{t} \mathrm{ha}^{-1}$ at 5.82, 5.63, and 5.71 $\mu \mathrm{mol} \mathrm{CO}_{2} \mathrm{mmol}^{-1} \mathrm{H}_{2} \mathrm{O}$ in $\mathrm{Ox} 1$, Ult, and Ox2 soils, respectively. $A / C_{i}$ showed a peak at $2.77,3.24$, and $2.51 \mathrm{t} \mathrm{ha}^{-1}$ at $0.38,0.44$, and 0.40 in $\mathrm{Ox} 1$, Ult, and $\mathrm{Ox} 2$ soils, respectively. $W U E$ is the amount of water transpired by a culture for the production of a certain quantity of dry matter (Silva et al., 2007). Thus, more efficient water use by crops can produce more dry matter per gram of water transpired. The most efficient use of water is directly related to stomatal opening time; as the plant absorbs $\mathrm{CO}_{2}$ for photosynthesis, water is lost by sweating with varying intensity, depending on the potential gradient between the leaf surface and the atmosphere and a stream of water potentials (Concenço et al., 2007). For $\mathrm{C}_{4}$ plants, even if the $\mathrm{CO}_{2}$ concentration in the leaf mesophyll reaches very low levels, plants continue to accumulate biomass because the enzyme responsible for primary carboxylation in these plants, PEP carboxylase, has a high affinity for $\mathrm{CO}_{2}$. This is possible because this group of plants has no detectable photorespiration (Silva et al., 2007). The $\mathrm{C}_{4}$ plants also use water more efficiently. With $\mathrm{CaSiO}_{3}$ application, $\mathrm{Si}$ is rapidly absorbed, which may confer beneficial effects on plants, such as reduced loss of water by transpiration (Barbosa Filho et al., 2001; Fageria et al., 2011), lodging resistance, more erect plants, improved photosynthetic efficiency (Tokura et al., 2011), and increased tolerance to pests (Goussain et al., 2002) and diseases (Prabhu et al., 2007; Buck et al., 2008; Rezende et al., 2009).

Agarie et al. (1998) studied the effect of $\mathrm{CaSiO}_{3}$ slag on rice, who observed lesser perspiration from stomatal pores after $\mathrm{CaSiO}_{3}$ application. They believed that reduced perspiration was linked to the density of the cuticle layer due to $\mathrm{Si}$ concentration. 
Table 1. Brazilian soil classification, approximate equivalence to soil taxonomy and sampling site of the three soils from Paraná State.

\begin{tabular}{lccc}
\hline Soil & Brazilian soil classification & Soil taxonomy & Sampling Municipality \\
\hline Ox1 & Eutroferric Red Latosol & Rhodic Acrudox & Marechal Cândido Rondon \\
Ox2 & Distroferric Red Latosol & Rhodic Hapludox & Cascavel \\
Ult & Red-Yellow Argisol & Arenic Hapludult & Goioerê \\
\hline${ }^{\dagger}$ According to Embrapa (2013). ${ }^{\dagger}$ USDA Soil Taxonomy (Soil Survey Staff, 2010). &
\end{tabular}
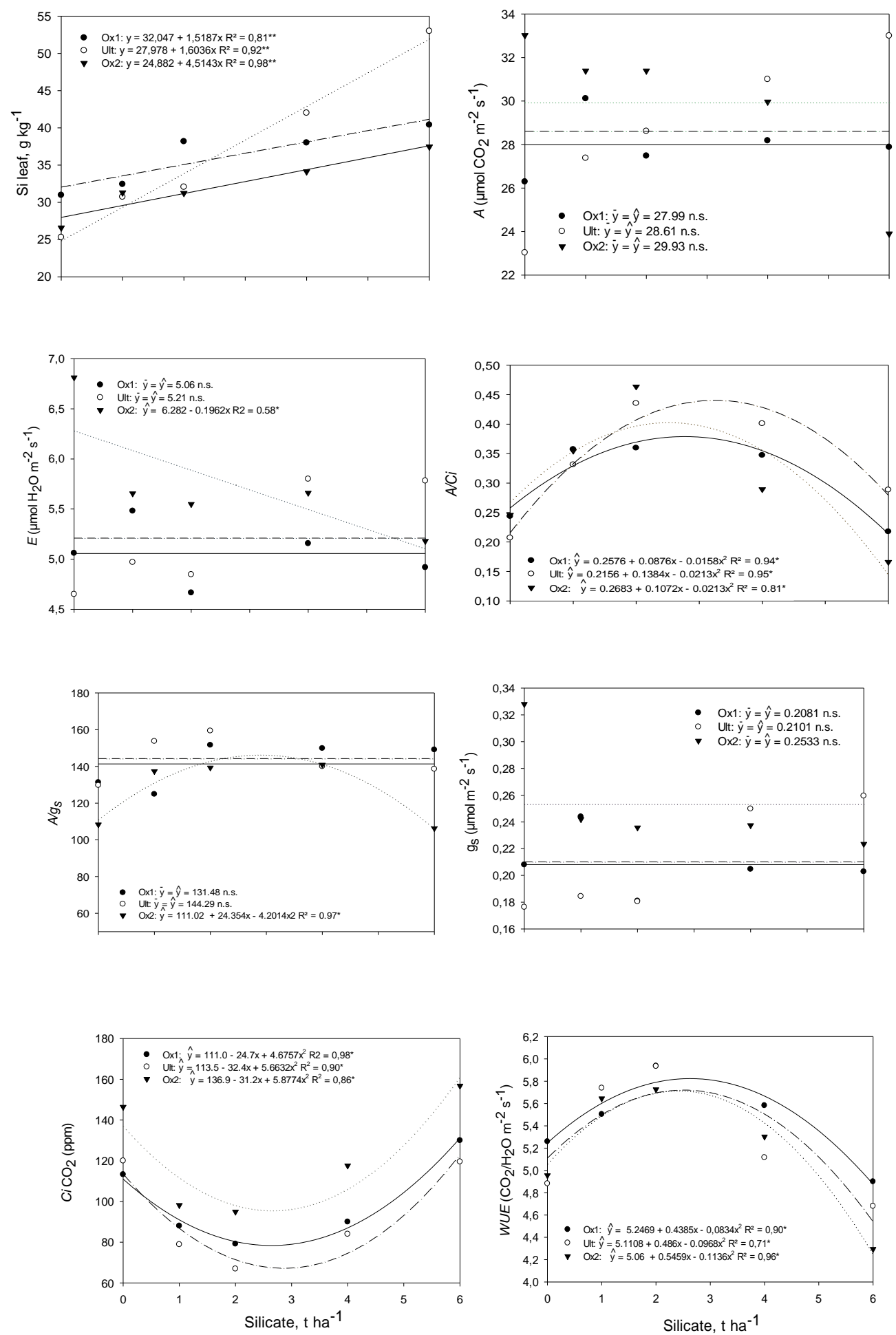

Fig 1. Mean values silicon leaf $(\mathrm{Si})$, photosynthesis $(A)$, stomatal conductance $\left(g_{s}\right)$, intercellular $\mathrm{CO}_{2}$ concentration $\left(C_{i} \mathrm{CO}_{2}\right)$, transpiration $(E)$, efficient use of water $(W U E)$, instantaneous efficiency carboxylation $\left(A / C_{i}\right)$ and intrinsic water use efficiency $\left(A / g_{s}\right)$, soils: Ox1 (-), Ult (--) and Ox2 (--). 
Table 2. Some physical and chemical properties of the soils.

\begin{tabular}{|c|c|c|c|}
\hline \multirow{2}{*}{ Soil characteristics } & \multicolumn{3}{|c|}{ Soil } \\
\hline & Acrudox & Hapludox & Hapludult \\
\hline Soil pH & 5.3 & 4.1 & 6.2 \\
\hline Clay $\left(\mathrm{g} \mathrm{kg}^{-1}\right)$ & 550.0 & 535.0 & 100.0 \\
\hline Silt $\left(\mathrm{g} \mathrm{kg}^{-1}\right)$ & 370.0 & 430.0 & 45.0 \\
\hline Sand $\left(\mathrm{g} \mathrm{kg}^{-1}\right)$ & 80.0 & 35.0 & 855.0 \\
\hline Organic matter $\left(\mathrm{g} \mathrm{kg}^{-1}\right)$ & 26.0 & 39.6 & 22.0 \\
\hline Available $\mathrm{P}\left(\mathrm{mg} \mathrm{kg}^{-1}\right)$ & 37.1 & 22.5 & 40.7 \\
\hline $\mathrm{H}+\mathrm{Al}\left(\mathrm{cmol}_{\mathrm{c}} \mathrm{kg}^{-1}\right)$ & 4.6 & 10.7 & 2.0 \\
\hline Exchangeable $\mathrm{Al}\left(\mathrm{cmol}_{\mathrm{c}} \mathrm{kg}^{-1}\right)$ & 0.0 & 2.4 & 0.0 \\
\hline Exchangeable $\mathrm{K}\left(\mathrm{cmol}_{\mathrm{c}} \mathrm{kg}^{-1}\right)$ & 0.15 & 0.20 & 0.20 \\
\hline Calcium $\left(\mathrm{cmol}_{\mathrm{c}} \mathrm{kg}^{-1}\right)$ & 4.8 & 4.0 & 2.5 \\
\hline Magnesium $\left(\mathrm{cmol}_{\mathrm{c}} \mathrm{kg}^{-1}\right)$ & 1.8 & 0.5 & 0.7 \\
\hline $\operatorname{CEC}\left(\mathrm{cmol}_{\mathrm{c}} \mathrm{kg}^{-1}\right)^{\dagger}$ & 11.4 & 15.4 & 5.4 \\
\hline Soil base saturation (\%) & 60.0 & 30.0 & 63.0 \\
\hline Copper $\left(\mathrm{mg} \mathrm{kg}^{-1}\right)$ & 15.0 & 8.2 & 9.9 \\
\hline $\operatorname{Zinc}\left(\mathrm{mg} \mathrm{kg}^{-1}\right)$ & 132.0 & 110.0 & 247.0 \\
\hline $\operatorname{Iron}\left(\mathrm{mg} \mathrm{kg}^{-1}\right)$ & 41.1 & 35.4 & 28.5 \\
\hline Manganese $\left(\mathrm{mg} \mathrm{kg}^{-1}\right)$ & 3.9 & 8.2 & 5.4 \\
\hline Silicon $\left(\mathrm{mg} \mathrm{kg}^{-1}\right)$ & 19.3 & 15.8 & 18.0 \\
\hline
\end{tabular}

CEC: cation exchange capacity.

Table 3. Mean values of height, number of tillers and green leaves Brachiaria according to the calcium silicate.

\begin{tabular}{|c|c|c|c|c|c|c|c|c|c|}
\hline \multirow{3}{*}{$\begin{array}{l}\text { Silicate } \\
\mathrm{t} \mathrm{ha}^{-1}\end{array}$} & \multicolumn{3}{|c|}{ Plant Height } & \multicolumn{3}{|c|}{ Tillers } & \multicolumn{3}{|c|}{ Green leaves } \\
\hline & Ox1 & Ox2 & Ult & Ox1 & Ox2 & Ult & Ox1 & Ox2 & Ult \\
\hline & \multicolumn{3}{|c|}{$-\mathrm{cm}-$} & & \multicolumn{4}{|c|}{$\mathrm{n}^{\mathrm{o}}$ plant -} & \\
\hline 0 & 35.0 & 40.8 & 32.9 & 8.1 & 7.2 & 7.3 & 4.5 & 4.1 & 4.6 \\
\hline 1 & 37.5 & 41.3 & 28.8 & 8.1 & 7.2 & 6.1 & 4.9 & 4.2 & 4.4 \\
\hline 2 & 31.1 & 38.7 & 33.5 & 6.8 & 6.3 & 5.6 & 4.5 & 4.3 & 4.7 \\
\hline 4 & 34.4 & 41.9 & 32.8 & 7.2 & 5.0 & 6.6 & 4.8 & 4.3 & 4.0 \\
\hline 6 & 32.2 & 39.4 & 35.2 & 7.4 & 7.4 & 6.4 & 4.9 & 3.8 & 5.0 \\
\hline Mean & $34.0 \mathrm{~b}$ & $40.4 \mathrm{a}$ & $32.6 \mathrm{~b}$ & $7.5 \mathrm{a}$ & 6.6ab & $6.4 \mathrm{~b}$ & $4.7 \mathrm{a}$ & $4.2 \mathrm{~b}$ & $4.5 \mathrm{a}$ \\
\hline \multicolumn{10}{|l|}{$F$ values } \\
\hline Soil & & $14.4^{* *}$ & & & $4.28^{*}$ & & & $6.9^{*}$ & \\
\hline Rates & & $0.30^{\mathrm{ns}}$ & & & $2.25^{\mathrm{ns}}$ & & & $0.35^{\mathrm{n}}$ & \\
\hline Soil Rates & & $0.99^{\mathrm{n}}$ & & & $0.88^{\mathrm{ns}}$ & & & $1.65^{\mathrm{n}}$ & \\
\hline CV $(\%)$ & & 18.2 & & & 18.9 & & & 10.8 & \\
\hline
\end{tabular}

** and * significant at $1 \%$ and $5 \%$ probability, respectively, by $\mathrm{F}$ test; ${ }^{\text {ns }}$ not significant. Means followed by the same lowercase letter on the line do not differ statistically by $5 \%$ Tukey test.

Table 4. Mean values of stem diameter, fresh and dry biomass of Brachiaria according to the calcium silicate.

\begin{tabular}{|c|c|c|c|c|c|c|c|c|c|}
\hline \multirow{2}{*}{ Silicate } & \multicolumn{3}{|c|}{ Stem diameter } & \multicolumn{3}{|c|}{ Fresh biomass } & \multicolumn{3}{|c|}{ Dry biomass } \\
\hline & Ox1 & $\mathrm{Ox} 2$ & Ult & Ox1 & Ox2 & Ult & Ox1 & Ox2 & Ult \\
\hline $\mathrm{t} \mathrm{ha}^{-1}$ & \multicolumn{3}{|c|}{$\mathrm{mm}$} & \multicolumn{5}{|c|}{- g plant $^{-1}$} & \\
\hline 0 & 4.7 & 4.7 & 5.1 & 65.2 & 96.3 & 50.5 & 19.3 & 22.5 & 18.2 \\
\hline 1 & 4.7 & 4.2 & 4.5 & 59.8 & 73.3 & 48.4 & 18.0 & 18.8 & 17.2 \\
\hline 2 & 5.0 & 4.3 & 4.7 & 67.7 & 78.9 & 39.7 & 19.5 & 20.1 & 16.4 \\
\hline 4 & 4.8 & 4.7 & 4.6 & 62.4 & 84.4 & 53.0 & 18.5 & 20.0 & 16.9 \\
\hline 6 & 5.2 & 4.7 & 4.7 & 63.4 & 71.4 & 46.1 & 18.9 & 19.7 & 17.8 \\
\hline Mean & 4.9 & 4.5 & 4.7 & $63.7 \mathrm{~b}$ & $80.86 a$ & $47.5 \mathrm{c}$ & $18.8 \mathrm{ab}$ & $20.2 \mathrm{a}$ & $17.3 \mathrm{c}$ \\
\hline \multicolumn{10}{|l|}{$F$ values } \\
\hline Soil & & $2.68^{\mathrm{n}}$ & & & $43.8^{* *}$ & & & $9.44^{* *}$ & \\
\hline Rates & & $1.34^{\mathrm{n}}$ & & & $1.90^{\mathrm{ns}}$ & & & $1.45^{\mathrm{ns}}$ & \\
\hline Soil' rates & & $0.63^{\mathrm{n}}$ & & & $1.17^{\mathrm{ns}}$ & & & $0.50^{\mathrm{ns}}$ & \\
\hline $\mathrm{CV}(\%)$ & & 10.11 & & & 17.6 & & & 11.3 & \\
\hline
\end{tabular}

** and * significant at $1 \%$ and $5 \%$ probability, respectively, by $\mathrm{F}$ test; ${ }^{\mathrm{ns}}$ not significant. Means followed by the same lowercase letter on the line do not differ statistically by $5 \%$ Tukey test.

In plants, Si fertilization reduces the values of $E$, resulting in less loss of water vapor. Furthermore, the plants start using water more efficiently and fix a greater amount of $\mathrm{CO}_{2}$ per molecule of water transpired. This is possible due to the accumulation of $\mathrm{Si}$, which provides mechanical protection to the skin and increases drought resistance because $\mathrm{Si}$ accumulated in the leaf blades form a double layer of silica cellulose and confer decreased permeability to water vapor, limiting the loss of water through the cuticle and reducing cuticle transpiration (Ma et al., 2001). The results support those obtained by Chen et al. (2011), who found reductions in $E$ and $C_{i}$ and dry matter accumulation in rice plants supplied with Si. Gao et al. (2006) also found a positive relationship between $\mathrm{Si}$ in leaves and decreased transpiration rate in wheat crop different water regimes. This highlights the best use of available soil water. According Rafi et al. (1997) and Korndörfer et al. (1999), use of $\mathrm{Si}$ in fertilization has advantages, especially in plants subjected to stress, whether 
biotic or abiotic. In this situation, accumulation of $\mathrm{Si}$ in the epidermal cells of grasses in particular results in upright leaves, increases light intensity over the plant canopy, reduces perspiration, prevents or reduces water stress in the foliage, and increases resistance to bedding (Cruciol, 2006). According to Epstein (2001), another action of $\mathrm{Si}$ is its ability to increase the chlorophyll content of leaves and plant tolerance to environmental stresses such as cold, heat, drought, nutritional imbalance, and metal toxicity.

\section{Production of components}

Plant height, tillers, green leaves, stem diameter, fresh biomass, and dry biomass were not influenced significantly $(\mathrm{p} \leq 0.05)$ by $\mathrm{CaSiO}_{3}$ (Tables 3 and 4 ). There was only a significant difference between the soils; signalgrass grown in Ox2 soil showed the highest height and fresh and dry biomass values. Korndörfer et al. (2010) investigated surface application of $\mathrm{CaSiO}_{3}$ on dry matter production in Brachiaria brizantha 'Marandu' and Panicum maximum 'Mombasa'; they observed higher Si concentration in the leaves, but Si did not affect the production of dry biomass, either in the first or second cut. Sávio et al. (2011) studied the use of different sources of $\mathrm{Si}$ on agronomic characteristics and leaf $\mathrm{Si}$ content in B. decumbens 'Basilisk' and P. maximum 'Mombasa'. They observed that, although $\mathrm{Si}$ was accumulated in the leaves of both species in the first cut, these differences were not sufficient to affect the vegetative growth of forage on the basis of the production of fresh materials, drought, and plant height.

\section{Materials and Methods}

\section{Study site description}

Pot experiments were performed in a greenhouse in Marechal Cândido Rondon, Paraná State, Brazil $\left(24^{\circ} 31^{\prime} \mathrm{S}, 54^{\circ} 01^{\prime} \mathrm{W}\right.$ and $420 \mathrm{~m}$ asl), where the environmental conditions were as follows: minimum and maximum mean air temperature of 18 and $36{ }^{\circ} \mathrm{C}$, respectively and mean air relative humidity of $65 \%$.

\section{Soils}

Surface samples $(0-0.2 \mathrm{~m})$ from three representative soils of the western region of Paraná State (Brazil) were selected for Si fertilization studies (Table 1). Physical and chemical properties of the soils were determined by adopting standard procedures, and some properties are listed in Table 2 . Soil $\mathrm{pH}$ in $0.01 \quad \mathrm{~mol} \quad \mathrm{~L}^{-1} \quad \mathrm{CaCl}_{2}$ solution was determined potentiometrically in a $1: 2.5$ (soil:solution) suspension by using a combined calomel-reference glass electrode and $\mathrm{pH}$ meter. Organic matter was quantified by oxidation with potassium dichromate in the presence of sulfuric acid, followed by titration with ammonium $\mathrm{Fe}$ (II) sulfate (Embrapa, 2009). Available P, exchangeable potassium (K), and cationic micronutrients $(\mathrm{Cu}, \mathrm{Zn}, \mathrm{Fe}$, and $\mathrm{Mn})$ were extracted using Mehlich-1 solution in a 1:10 (w:v) soil-toextract solution ratio (Embrapa, 2009); P was determined using colorimetry at $725-\mathrm{nm}$ wavelength, and $\mathrm{K}$ and micronutrients were determined using atomic absorption spectrophotometry.

$\mathrm{Ca}$ and magnesium $(\mathrm{Mg})$ were extracted by $1 \mathrm{~mol} \mathrm{~L}^{-1} \mathrm{KCl}$ solution and determined using atomic absorption spectrophotometry. Cation exchange capacity (CEC) was estimated using the summation method (CEC $=\mathrm{H}+\mathrm{Al}+\mathrm{Ca}$ $+\mathrm{Mg}+\mathrm{K})$. Soluble Si was extracted by $0.5 \mathrm{~mol} \mathrm{~L}^{-1}$ acetic acid solution in a 1:10 (w:v) soil-to-extractant solution ratio (Korndörfer et al., 1999) and determined by beta molybdosilicic complex formation with a spectrophotometer at 660-nm wavelength. Particle size analysis was performed using the pipette method (Embrapa, 2009), according to decantation speed of different soil particles after dispersion in $0.015 \mathrm{~mol} \mathrm{~L}^{-1}\left(\mathrm{NaPO}_{3}\right) 6 . \mathrm{NaO} / 1 \mathrm{~mol} \mathrm{~L}^{-1} \mathrm{NaOH}$ by overnight shaking.

\section{Experimental design and treatments}

The experimental design was a $3 \times 5$ factorial in complete randomized blocks, with four replications. Treatments consisted of three soils-Ox1, Ox2, and Ult-and wheat plants grown using 0 (control), 1, 2, 4, and $6 \mathrm{t} \mathrm{ha}^{-1}$ of $\mathrm{CaSiO}_{3} / \mathrm{MgSiO}_{3}$. The silicate source used was AgroSilício ${ }^{\circledR}$ $(10.5 \% \mathrm{Si}, 25 \% \mathrm{Ca}, 6 \% \mathrm{Mg}$, and $88 \%$ effective calcium carbonate equivalent (ECCE). The corrected soils were maintained for 15 days with water content at $60 \%$ field capacity. Then, the soils were placed in 8-L plastic pots and fertilized by applying $30 \mathrm{mg} \mathrm{kg}^{-1}$ of $\mathrm{N}$ (urea), $80 \mathrm{mg} \mathrm{kg}^{-1}$ of $\mathrm{P}$ (simple superphosphate), and $60 \mathrm{mg} \mathrm{kg}^{-1}$ of $\mathrm{K}(\mathrm{KCl})$.

\section{Plant material}

Twenty seeds of the Brachiaria hybrid 'Mulato II' (Convert HD364) were sown, and they were thinned to three plants per pot nine days after seedling emergence. The pots were irrigated daily to maintain soil moisture at near field capacity.

\section{Gas exchange measurement}

Gas exchange was performed at 45 days after sowing (DAS) by using a portable infrared gas analyzer (IRGA; open system, LICOR 6400 XT). Evaluation of gas exchange was performed using completely expanded leaves on a sunny day. The following parameters were evaluated: $A\left(\mu \mathrm{mol} \mathrm{CO}_{2} \mathrm{~m}^{-2}\right.$ $\left.\mathrm{s}^{-1}\right), g_{s}\left(\mathrm{mmol} \mathrm{H}_{2} \mathrm{O} \mathrm{m}^{-2} \mathrm{~s}^{-1}\right), E\left(\mathrm{~mol} \mathrm{H}_{2} \mathrm{O} \mathrm{m} \mathrm{m}^{-2} \mathrm{~s}^{-1}\right.$, and $\mathrm{C}_{i} \mathrm{CO}_{2}$ (substomatic ppm within the chamber). We calculated the physiological efficiency of $W U E$ by the ratio of the rate of $\mathrm{CO}_{2}$ assimilation to $A / E\left(\mu \mathrm{mol} \mathrm{CO}_{2} \mathrm{mmol}^{-1} \mathrm{H}_{2} \mathrm{O}\right), A / C$, and $A / g_{s}$. During the evaluation of gas exchange, air temperature varied from $29.4^{\circ} \mathrm{C}$ to $33.8^{\circ} \mathrm{C}$, average relative humidity was $60.6 \%$, photon density of the external environment provided by the device showed an average of $767.7 \mu \mathrm{mol} \mathrm{m} \mathrm{m}^{-2} \mathrm{~s}^{-1}$, and photon flux in the IRGA chamber was $1,200 \mu \mathrm{mol} \mathrm{m} \mathrm{m}^{-2} \mathrm{~s}^{-1}$. The plants were harvested at 45 DAS, and we measured fresh and dry biomass $\left(\mathrm{g}\right.$ plant $\left.{ }^{-1}\right)$, plant height $\left(\mathrm{cm} \mathrm{plant}^{-1}\right)$, tillers $\left(n^{\circ}\right.$ plant $\left.^{-1}\right)$, leaves $\left(n^{\circ}\right.$ plant $\left.^{-1}\right)$, stem diameter $(\mathrm{mm})$, and $\mathrm{Si}$ in the leaf by digestion with hydrogen peroxide and sodium hydroxide and then using colorimetry (Korndörfer et al., 2004).

\section{Statistical analysis}

Original data were analyzed using analysis of variance and regression analysis, and significant equations with the highest coefficients of determination (Tukey test, $\mathrm{p} \leq 0.05$ ) were adjusted. All analyses were performed using Saeg 8.0 software for Windows (Statistical Analysis Software, UFV, Viçosa, MG, BRA).

\section{Conclusions}

Application of calcium silicate to the soil increases the concentration of $\mathrm{Si}$ in the leaves. $\mathrm{Si}$ in plants reduces internal $\mathrm{CO}_{2}$ concentration and increases the efficiency of water use 
and instantaneous carboxylation efficiency. In soils with low $\mathrm{pH}$ and a high $\mathrm{Al}^{+3}$ level, which is toxic, reduction in plant sweating increases the intrinsic efficiency of water use in Brachiaria. Si helped to alleviate the toxic effects of $\mathrm{Al}^{+3}$.

\section{Acknowledgments}

To CAPES (Coordination for the Improvement of Higher Education Personnel), for financial support and providing scholarship to the first author.

\section{References}

Agarie S, Uchida H, Agata W, Kubota F, Kaufman PB (1998) Effects of silicon on transpiration and leaf conductance in rice plants (Oryza sativa L.). Plant Prod Sci. $1: 89-95$.

Barbosa Filho MP, Snyder GH, Fageria NK, Datnoff LE, Silva OF (2001) Calcium silicate as source of silicon for upland rice. Rev Bras Ciênc Solo. 25:325-330.

Barducci RS, Costa C, Crusciol CAC, Borghi E, Putarov TC, Sarti LMN (2009) Production of Brachiaria brizantha and Panicum maximum with corn and nitrogen fertilization. Archivos de Zootecnia. 58:211-222.

Braga GJ, Mello ACL, Pedreira CGS, Medeiros HR (2009) Photosynthesis and daily forage productivity of Tanzania guinea grass pastures under rotational stocking. Pesq Agropec Bras. 44:84-91.

Buck GB, Korndörfer GH, Nolla A, Coelho L (2008) Potassium silicate as foliar spray and rice blast control. J Plant Nutr. 31:231-237.

Chen W, Yao X, Cai K, Chen J (2011) Silicon alleviates drought stress of rice plants by improving plant water status, photosynthesis and mineral nutrient absorption. Biol Trace Element Residuos. 142:67-76.

Cocker KM, Evans DE, Hodson MJ (1998) The amelioration of aluminum toxicity by silicon in higher plants: solutions chemistry or in plant mechanism? Physiol Plant. 104:608614.

Concenço G, Ferreira EA, Silva AA, Ferreira FA, Viana RG, D'antonino L, Vargas L, Fialho CMT (2007) Water use in Italian ryegrass (Lolium multiflorum) biotypes under competition. Planta Daninha. 25:449-455.

Concenço G, Ferreira EA, Silva AA, Ferreira FA, Galon L, Reis MR, D'antonino L, Vargas L, Silva LVBD (2008) Photosynthesis of ryegrass biotypes under different competition levels. Planta Daninha. 26:595-600.

Cruciol CAC (2006) Silicon for forage grasses. Revista Campo e Negócios, Uberlândia. 4:14-15.

Dann EK, Muir S (2002) Peas growth in media with elevated plantavailable silicon levels have higher activities of chitinase and $\alpha-1,3$ glucanase, are less susceptible to a fungal leaf spot pathogen and accumulate more foliar silicon. Austr. Plant Pathol. 31:9-13.

Datnoff, LE, Snyder GH, Korndörfer GH (2001) Silicon in agriculture. Amsterdam: Elsevier, 403 p.

Dayanandam P, Kaufman PB, Frakin C I (1983) Detection of silica in plants. Amer J Bot. 70:1079-1084.

Deren C (2001) Plant genotypes, silicon concentration and silicon related responses. In: Datnoff LE, Snyder GH \& Korndörfer GH Silicon In Agriculture. 8:149-158.

Dias-Filho MB (2002) Photosynthetic light response of the C4 grasses Brachiaria brizantha and B. humidicola under shade. Sci Agric. 59:65-68.
Dias GMG, Rodrigues Soares JD, Pasqual M, Lara Silva RA, Rodrigues LCA, Pereira, FJ, Castro EM (2014) Photosynthesis and leaf anatomy of 'Anthurium' cv. Rubi plantlets cultured 'in vitro' under different silicon (Si) concentrations. Aust J Crop Sci. 8:1160-1167.

Embrapa - Empresa Brasileira de Pesquisa Agropecuária. (2009) Manual de análises químicas de solos, plantas e fertilizantes. 2.ed. Brasília, Informação Tecnológica, 628 p.

Epstein E (2001) Silicon in plants: facts vs concepts. In: Datnoff LE, Snyder GH, Korndörfer GH (Eds.). Silicon in Agriculture. The Netherlands: Elsevier Science, 403 p.

Fageria NK, Baligar VC, Jones CA (2011) Growth and Mineral Nutrition of Field Crops. Boca Raton: CRC Press, $640 \mathrm{p}$.

Ferraz RLS, Melo AS, Suassuna JF, Brito MEB, Fernandes PD, Nunes Júnior ES (2012) Gas exchange and photosynthetic efficiency in common bean ecotypes grown in a semiarid environment. Pesq Agropec Trop. 42:181188.

Ferraz RL de S, Beltrão NE de M, Melo AS de; Magalhaes ID, Fernandes PD, Rocha M do S (2014) Gas exchange and photochemical efficiency of cotton cultivars under leaf application of silicon. Semina. 35:735-748.

Fonseca IM, Prado RM, Vidal AA, Nogueira TAR (2009) Effect of slag, lime and nitrogen in silicon absorption and production of the marandu palisadegrass. Bragantia. 68:53-61

Gao X, Zou C, Wang L, Zhang F (2006) Silicon decreases transpiration rate and conductance from stomata of maize plants. J Plant Nutr. 29:1637-1647.

Gong H, Chen K (2012) The regulatory role of silicon on water relations, photosynthetic gas exchange, and carboxylation activities of wheat leaves in field drought conditions. Acta Physiol Plant. 34:1-6.

Goussain MM, Moraes JC, Carvalho JG, Nogueira NL, Rossin M (2002) Effect of silicon application on corn plants upon the biological development of the fall armyworm Spodoptera frugiperda (J.E. Smith) (Lepidoptera: Noctuidae). Neotrop Entomol. 31:305-310.

Hanba YT, Kogami H, Terashima L (2002) The effects of growth irradiance on leaf anatomy and photosynthesis in Acer species differing in light demand. Plant Cell Environ. 25:1021-1030.

Inoue MT, Ribeiro FA (1998) Photosynthesis and transpiration clones Eucalyptu ssp. and E. saligna. Revista do IPEF. 40:15-20.

Korndörfer G H, Coelho NM, Snyder DH, Mizutani CT (1999) Evaluation of silicon extraction methods for soils under upland rice. Rev Bras Ciênc Solo. 23:101-103.

Korndörfer G, Snyder GH, Ulloa M, Powell G, Datnoff LE (2001) Calibration of soil and plant silicon analysis for rice production. J Plant Nutr. 24:1071-1084.

Korndörfer GH, Pereira HS, Nolla A (2004) Silicon analysis: soil, plant and fertilizer. Uberlândia: GPSi/ICIAG/UFU, 2004. 34 p. (Technical Bulletin, 2).

Korndörfer PH, Silva GC, Teixeira IR, Silva AG, Freitas RS (2010) Silicon fertilization effect on grasses and soil chemical properties. Pesq Agropec Trop. 40:119-125.

Ma, JF, Yamaji N (2008). Functions and transport of silicon in plants. Cel Molec Life Sci. 65:3049-3057.

Ma, JF, Yamaji N (2006). Silicon uptake and accumulation in higher plants. Trends Plant Sci. 11:342-397.

Ma JF, Miyake Y, Takahashi E (2001) Silicon as a beneficial element for crop plants. In: Datnoff LE, Sneder GH, Korndörfer GH (Ed.). Silicon in Agriculture. Amsterdam: Elsevier Science, p 17-39. 
Marschner H (1995) Mineral Nutrition of Higher Plants. 2ed. London: Academics Press, 889p.

Motomura H, Mita N, Suzuki M (2002) Silica accumulation in long-lived leaves of Sasa veitchii (Carriére) rehder (Poaceae-Bambusoideae). Ann Bot. 90:149-152.

Pereira HS, Korndörfer GH, Vidal AA, Camargo MS (2004) Silicon sources for rice crop. Sci Agric. 61:522-528.

Prabhu AS, Santos AB, Didonet AD (2007) Soluble tissue sugar content and leaf blast severity in response to the application of calcinated serpentinite as a silicon source in irrigated rice. Summa Phytopathol. 33:402-404.

Rafi MM, Epstein E, Falk RH (1997) Silicon deprivation causes physical abnormalities in wheat (Triticum aestivum L.). J Plant Physiol. 151:497-501.

van Raij B (1991) Soil fertility and fertilization. Piracicaba: Ceres, Potafos, 343 p.

Rezende DC, Rodrigues FA, Carré-Missio V, Schurt DA, Schurt DA, Kawamura IK (2009) Effect of root and foliar applications of silicon on brown spot development in rice. Aust Plant Pathol. 38:67-73.

Rizwan M, Meunier J-D, Miche H, Keller C (2012) Effect of silicon on reducing cadmium toxicity in durum wheat (Triticum turgidum L. cv. Claudio W.) grown in a soil with aged contamination. J Hazard Materials. 209:326-334.

Sano EE, Rosa R, Brito JLS, Ferreira LG (2008) Semidetailed land use mapping in the Cerrado. Pesq Agropec Bras. 43:153-156.

Sarto MVM, Lana MC, Rampim L, Rosset JS, Wobeto JR (2015) Effects of silicate application on soil fertility and wheat yield. Semina. 36:4071-4082.
Sarto MVM, Rampim L, Lana MC, Rosset J, Ecco M, Wobeto J (2014a) Attributes of soil chemical and development of culture wheat for each silicon fertilization. Agrarian. 7:390-400.

Sarto MVM, Lana MC, Rampim L, Rosset JS, Wobeto JR, Ecco M, Bassegio D, Costa PF (2014b) Effect of silicate on nutrition and yield of wheat. Afr J Agri Res. 9:956-962.

Sávio FL, Silva GC, Teixeira IR, Borém A (2011) Biomass production and silicon content in forages under different sources of silicate. Semina. 32:103-110.

Silva AA, Ferreira FA, Ferreira LR (2007) Biology of weeds. Cap.1, p.1-40. In: Topics in Weed Management. Ed. UFV. Viçosa - MG. 300 p.

Tokura AM, Furtini Neto AE, Carneiro LF, Curi N, Santos JZL, Alovisi AA (2011) Dynamics of phosphorus forms in soils with contrasting texture and mineralogy cultivated with rice. Acta Sci Agron. 33:171-179.

Vitorello VA, Capaldi FR, Stefanuto VA (2005) Recent advances in aluminum toxicity and resistance in higher plants. Braz J Plant Physiol. 17:129-143.

Wang J, Raman H, Zhang G, Mendham N, Zhou M (2006) Aluminum tolerance in barley (Hordeum vulgare L.): physiological mechanisms, genetics and screening methods. J Zhejiang Univ Sci B. 7:769-787. 